\title{
APLIKASI METODE AL-GHOYAH DALAM PENINGKATAN KUALITAS PEMBELAJARAN KITAB KUNING (Studi di Pondok Pesantren Bahrul Ulum Desa Sumur Dalam Kecamatan Besuk Probolinggo Tahun Pelajaran 2018-2019)
}

\author{
Firdaus Ainul Yaqin \\ Institut Ilmu Keislaman Zainul Hasan Genggong, Indonesia \\ Firdoz10@gmail.com \\ Nur Fatimah \\ Institut Ilmu Keislaman Zainul Hasan Genggong, Indonesia \\ nurfatimahsholeh@gmail.com
}

\begin{abstract}
Kitab kuning is a peculiarity of pesantren as one of Islamic educational institutions, or as a mainstay in the field of education. In applying the Kitab kuning there are several methods for mastering and understanding the learning of the Kitab kuning. The most common method in learning the yellow book is the sorogan and wetonan methods. However, in the Bahrul Ulum Islamic Boarding School using a method known as the Al-Ghoyah Method. From the above explanation, this research can be formulated as follows: 1 . How is the application of the al-ghoyah method to the boarding school Bahrul Ulum? 2. What are the advantages and disadvantages of the application of the al-Ghoyah method? The research approach used is qualitative research, while the type of research is descriptive. In collecting data using the method of observation / observation, interviews, documentation. The results obtained from research at the boarding school Bahrul Ulum are 1. Application of the AlGhoyah Method at the Boarding School of Bahrul Ulum, namely by carrying out three stages, namely, preparation, implementation and evaluation. 2. Strengths and weaknesses of the AlGhoyah Method at the Bahrul Ulum Islamic Boarding School, namely Strengths: fast in reading and understanding the Kitab kuning within 20 days, applying methods that are easily accepted by students, appearance of reading the Kitab kuning when Haflatul Ikhtibar, following the competition in the field of $\mathrm{Al}$-Jurumiyah. The disadvantage is the lack of guidance from the Al-Ghoyah Method, students must have an understanding of the science of tools, as well as the high costs incurred.
\end{abstract}

Keywords: Al-Ghoyah Method, Kitab kuning Learning Quality.

Abstrak: Kitab kuning merupakan kekhasan pesantren sebagai salah satu institusi pendidikan islam, atau sebagai andalan dalam kancah pendidikannya. Dalam penerapan kitab kuning itu terdapat beberapa metode untuk menguasai dan memahami pembelajaran kitab kuning. Metode yang paling umum dalam pembelajaran kitab kuning adalah metode sorogan dan wetonan. Akan tetapi di Pondok Pesantren Bahrul Ulum menggunakan metode yang dikenal dengan Metode Al-Ghoyah. Dari pemaparan di atas maka penelitian ini dapat dirumuskan sebagai berikut: 1. Bagaimana aplikasi metode al-ghoyah pada pesantren Bahrul Ulum? 2. Apa kelebihan dan kekurangan aplikasi metode al-ghoyah? Pendekatan penelitian yang digunakan adalah penelitian kualitatif, Sedangkan jenis penelitianya adalah deskriptif. Dalam pengumpulan data dengan menggunakan metode pengamatan/observasi, wawancara, 
dokumentasi. Hasil yang didapatkan dari penelitian di pondok pesantren Bahrul Ulum adalah 1. Aplikasi Metode Al-Ghoyah di Pondok Pesantren Bahrul Ulum yaitu dengan melakukan tiga tahapan yaitu, persiapan, pelaksanaan dan evaluasi. 2. Kelebihan dan kekurangan Metode Al-Ghoyah di Pondok Pesantren Bahrul Ulum yaitu Kelebihan: cepat dalam membaca dan memahami Kitab Kuning dalam waktu 20 hari, penerapan metode yang mudah diterima oleh santri, penampilan pembacaan Kitab Kuning ketika Haflatul Ikhtibar, mengikuti lomba dalam bidang Al-Jurumiyah. Kekurangannya adalah kurangnya pembimbing Metode AlGhoyah, santri harus punya pemahaman terhadap ilmu alat, serta mahalnya biaya yang harus dikeluarkan.

Kata Kunci: Metode Al-Ghoyah, Kualitas Pembelajaran Kitab Kuning.

\section{A. PENDAHULUAN}

Pesantren merupakan lembaga pendidikan dan pengajaran Islam dimana di dalamnya terjadi interaksi antara kiai atau ustadz sebagai guru dan para santri sebagai murid dengan mengambil tempat di masjid atau pada koridor asrama (pondok) untuk mengaji dan mempelajari buku-buku teks keagamaan karya ulama' masa lalu. ${ }^{1}$

Sebagai lembaga pendidikan, pondok pesatren sangat berpotensi dalam usaha pemberdayaan masyarakat, terutama pada masyarakat sekitar pondok pesantren, termasuk upaya transformasi sosial yang akan dilakukan oleh pondok pesantren. Sebab dalam upaya yang demikian, sebaiknya ditempuh melalui pendayagunaan modal dan potensi kultural yang telah dimiliki oleh pondok pesantren. ${ }^{2}$ Potensi yang dimiliki itu antara lain: jumlah yang sangat besar, mengakar dan dipercaya pada masyarakat, lokasinya di daerah pedesaan, fleksibilitas waktu, dan sebagai lembaga pengembangan dan pembentukan watak.

Pesantren sejak kemunculannya di belahan wilayah Nusantara, khususnya di Jawa, dikenal sebagai tempat untuk menimba ilmu agama (Islam). Dianggap sebagai pesantren pertama di Jawa yang didirikan oleh Syeikh Malik Ibrahim atau lebih dikenal dengan Syeikh Maghribi, salah satu Walisongo penyebar Islam di wilayah jawa. Kemudian berkembang pesantren-pesantren di berbagai daerah dengan ciri dan karakteristiknya masing-masing 3 .

\footnotetext{
${ }^{1}$ Depag RI, Pola Pembelajaran di Pesantren, (Jakarta, 2003), hlm. 3.

2 Depag RI, Pola Pengembangan Pondok Pesantren, (Jakarta, 2003), hlm. 26.

${ }^{3}$ Ahmad Arifi, Politik Pendidikan Islam, (Yogyakarta: Sukses Offset, 2010), hlm. 104.
} 
Ciri khas utama dari pesantren adalah pembelajaran kitab-kitab klasik, atau yang lebih sering dikatakan kitab kuning. Menurut Masdar F Mas'udi sebagamana dikutip oleh Nurul Hanani, selama ini berkembang tiga terminologi mengenai kitab kuning. Pertama, kitab kuning adalah kitab yang ditulis oleh ulama klasik Islam yang secara berkelanjutan dijadikan referensi yang dijadikan pedoman oleh para ulama Indonesia, seperti Tafsir Ibn Katsir, Tafsir al-Khazin, Shahih Bukhari, Shahih Muslim, dan sebagainya. Kedua, kitab kuning adalah kitab yang ditulis oleh ulama Indonesia sebagai karya tulis yang independen, seperti Imam Nawawi dengan kitabnya Mirah Labid dan Tafsir al-Munir. Ketiga, kitab kuning adalah kitab yang ditulis oleh ulama Indonesia sebagai komentar atau terjemahan atas kitab karya ulama asing, kitab-kitab Kyai Ihsan Jampes, yaitu Siraj al-Thalibin dan Manahij alImdad, yang masing-masing merupakan komentar atas Minhaj al-'Abidin dan Irsyad al- 'Ibad karya Al Ghazali. ${ }^{4}$

Dalam pengkajian kitab kuning, terdapat beberapa metode yang metode sorogan, bandongan dan wetonan yang dinilai sangat efektif dalam penyampaian khazanah-khazanah dalam kitab kuning. ${ }^{5}$ Selain ketiga metode tersebut terdapat pula metode-metode yang baru seperti metode Amshilati yang dinilai sangat membantu santri agar lebih mudah untuk mempelajari kita kuning. ${ }^{6}$

Akan tetapi, dalam beberapa kasus, metode-motode di atas tidak memberi respon yang positif bagi santri. Seperti pada Pondok Pesantren Bahrul Ulum. Pada mulanya, metode yang digunakan dalam pondok tersebut adalah Metode Amshilati, meski sudah bertahun-tahun menggunakan metode tersebut, kemampuan santri tetap tidak ada peningkatan, tetap tidak tahu membaca, apalagi mau mengartikan dari lafadz satu ke lafadz lain. Penyebab utama dari kegagalan metode ini adalah kondisi dan situasi santri yang membuat tidak dapat melakukan hafalan dengan

4 Nurul Hanani, "Managemen Pengembangan Pembelajaran Kitab Kuning", dalam Jurnal Realita Vol. 15 No. 2 (2017), hlm. 1-25

5 Azuma Fela Sufa, "Efektifitas Metode Pembelajaran Kitab Kuning di Madrasah Diniyah Pondok Pesantren Al-Mahalli Brajan Wonokromo Pleret Bantul Tahun Ajaran 2013/2014", dalam jurnal Literasi Vol. V No. 2 (2014), hlm. 169-186.

${ }^{6}$ Ahmad Hamdani, "Metode Praktis Buku Amtsilati dalam Peningkatan Baca Kitab Kuning di Pondok Pesantren", dalam Jurnal Pendidikan Islam An Nida Pasca PAI Uninus Vol 6 No 1 (2017), hlm 2434. 
baik. Hingga pada akhirnya, pada tahun 2013 PP Bahrul Ulum melakukan perubahan Metode Pembelajaran kitab kuning, dari metode amshilati ke metode ghoyah. Perubahan ini kemudian memberi dampak positif terhadap perkembangan santri dalam membaca kitab kuning. Santri dapat lebih cepat menghafal kaidahkaidah nahwu yang menjadi dasar untuk dapat membaca kitab kuning. ${ }^{7}$

Penelitian dengan judul "Aplikasi Metode Al-ghoyah dalam Peningkatan Kualitas Pembelajaran Kitab Kuning di Pondok Pesantren Miftahul Huda", menggunakan metode penelitian kualitatif deskriptif dengan teknik pengumpulan data berupa observasi, wawancara, dan dokumentasi.

\section{B. PONDOK PESANTREN}

1. Pengertian Pondok Pesantren

Menurut HA Timur Jailani memberikan batasan pesantren adalah gabungan dari berbagai kata pondok dan pesantren,istilah pesantren diangkat dari kata santri yang berarti murid atau santri yang berarti huruf sebab dalam pesantren inilah mula-mula santri mengenal huruf, sedang istilah pondok berasal dari kata funduk (dalam bahasa arab) mempunyai arti rumah penginapan atau hotel. ${ }^{8}$ Sedangkan menurut pendapat yang lain, kata pesantren berasal dari kata santri yang dengan awalan pe dan akhiran an, yang menentukan tempat, berarti "tempat tinggal para santri". Jadi pondok pesantren adalah asrama tempat tinggal para santri ${ }^{9}$.

Pesantren merupakan lembaga pendidikan tradisional yang lahir dan tumbuh beriringan dengan hadirnya Islam ke bumi Jawa. Dengan demikian, pesantren merupakan institusi pendidikan tertua dan murni (indegenous) dalam masyarakat indonesia. ${ }^{10}$ Secara terminologis, pondok pesantren adalah sekolah tradisional islam berasrama di indonesia. Institusi pengajaran inimemfokuskan pada pengajaran agama dengan menggunakan metode pengajaran tradisional dan mempunyai

\footnotetext{
${ }^{7}$ Berdasarkan hasil wawancara dengan pengurus PP. Bahrul Ulum

${ }^{8}$ M. Syamsudini, Kontribusi Model Pendidikan Pondok Pesantren Darunnajah Kabubaten Banyuwangi (Jember: STAIN Jember, 2008), hlm. 379.

${ }^{9}$ Khotibul Umam, Pernak-Pernik Pesantren (Jember: Pustaka Radja, 2012), hlm. 5.

10 Muhammad Muchlis solichin, Masa Depan Pesantren, (Surabaya: Salsabila Putra Pratama, 2013), hlm. 35.
} 
aturan-aturan administrasi dan kurikulum pengajaran yang khas ${ }^{11}$. Sehingga pondok pesantren adalah salah satu lembaga pendidikan Islam tertua di Indonesia yang dianggap sebagai lembaga pendidikan tradisional mempunyai karakteristik sendiri dan berbeda dengan lembaga-lembaga pendidikan Islam lainnya.

\section{a. Tipologi Pondok Pesantren}

Pondok pesantren sebagai lembaga pendidikan islam mengalami perkembangan bentuk sesuai dengan perubahan zaman, terutama sekali adanya kemajuan ilmu pengetahuan dan teknologi. Perubahan bentuk pesantren bukan berarti sebagai pondok pesantren yang telah hilang kekhasannya. Dalam hal ini pondok pesantren tetap merupakan lembaga pendidikan Islam yang tumbuh dan berkembang dari masyarakat untuk masyarakat ${ }^{12}$.

Secara faktual ada beberapa tipe pondok pesantren yang berkembang dalam masyarakat ${ }^{13}$, yang meliputi:

a. Pondok pesantren tradisional

Pondok pesantren ini masih tetap mempertahankan bentuk aslinya dengan semata-mata mengajarkan kitab yang ditulis oleh Ulama' abad ke 15 dengan menggunakan bahasa arab. Pola pengajarannya dengan menerapkan Sistem Halaqah (penghafalan) yang dilaksanakan di Masjid atau Surau. Kurikulumnya tergantung sepenuhnya kepada para kiai pengasuh pondoknya. Santrinya ada yang menetap(mukim) dan santri yang tidak menetap (santri kalong).

Dalam konteks Islam Tradisional, ada lima unsur yang menandai tradisi pesantren, yaitu : kyai, santri, pengajian kitab-kitab islam klasik, pondok, dan masjid. Dengan lima unsur itu, pesantren merupakan simbol kekuatan Islam Tradisional dalam fenomena keagamaan dan sosial.

b. Pondok pesantren modern

Pondok pesantren ini merupakan pengembangan tipe pesantren karena orientasi belajarnya cenderung mengadopsi seluruh sistem belajar secara

${ }^{11}$ Ahmad Mutohar, Nurul Anam, Manifesto Modernisasi Pendidikan Islam dan Pesantren, (Jember: Pustaka Pelajar \& STAIN Jember, 2013), hlm. 142.

12 Bahri Ghazali, Pesantren Berwawasan Lingkungan, (Jakarta: Prasasti, 2002), hlm. 13-15.

${ }^{13}$ M. Syamsudini, Kontribusi Model Pendidikan , hlm. 381. 
klasik dan meninggalkan sistem belajar tradisional. Penerapan sistem belajar modern ini terutama nampak pada penggunaan kelas-kelas belajar baik dalam bentuk madrasah maupun sekolah. Kurikulum yang dipakai adalah kurikulum sekolah atau madrasah yang berlaku secara nasional.

c. Pondok pesantren komprehensif

Pondok pesantren ini disebut komprehensif karena merupakan sistem pendidikan dan pengajaran gabungan antara yang tradisional dan yang modern. Artinya di dalamnya diterapkan pendidikan dan pengajaran kitab kuning dengan metode sorogan, bandongan dan wetonan, namun secara reguler sistem persekolahan terus dikembangkan.

\section{b. Pengembangan Potensi Pesantren}

Pada era kemajuan saat ini, perkembangan pendidikan pesantren mencapai puncaknya dengan timbulnya konsepsi pendidikan pesantren baru yang berbeda dengan konsep pendidikan pesantren yang sudah ada dan telah berkembang.

Sementara itu, direktur jenderal pendidikan Islam kementrian agama, Mohammad Ali menegaskan bahwa mengingat kemajuan teknologi yang demikian pesat, maka para santri seharusnya tidak hanya memiliki kemampuan di dalam memahami kitab kuning, akan tetapi juga harus memiliki bidang-bidang yang lain sehingga dengan kemampuannya tersebut bisa memberikan manfaat kepada lebih banyak orang. ${ }^{14}$ Akan tetapi, dalam pengembangan pesantren dimana perlu adanya adaptasi kajian keilmuan, kajian-kajian lama yang sudah ada perlu tetap dipertahankan sebagai ciri khas utamanya. Salah satu ciri khas utamanya adalah kitab kuning. Oleh karena itu, seiring perkembangan zaman, metode pembelajaran kitab kuning juga mengalami perkembangan dan inovasi.

2. Pondok Pesantren Bahrul Ulum

Pondok Pesantren Bahrul Ulum adalah salah satu pesantren yang terletak di desa Sumur Dalam kecamatan Besuk Kabubaten Probolinggo. Pesantren ini didirikan oleh K.H. Muhammad Amiri pada tahun 1995. Pesantren ini didirikan

${ }^{14}$ Babun suharto, Dari Pesantren Untuk Umat, (Surabaya: Imtiyaz, 2011), hlm. 124. 
karena banyaknya minat santri untuk mukim di tempat tersebut, yang pada awalnya hanya berupa Langgar.

Saat ini, pesantren tersebut diasuh oleh K.H. Achmad Zaini, dengan jumlah santri mukim secara keseluruhan 152, yang terdiri dari santri putra 60 dan putri 92. Selain itu, juga terdapat santri kalong sebanyak 87 orang, yang berasal dari lingkungan sekitar pesantren.

Pondok tersebut dari tahun ke tahun mengalami pasang surut, baik dari jumlah santri maupun kualitas yang mencakup kualitas pembelajaran maupun jumlah santri. Penyebab terjadinya pasang surut tersebut di karenakan: Pertama, Metode Pengajarannya yang menuntut untuk hafalan, sedangkan santri sebagian besar tidak mampu untuk melakukan hafalan; dan Kedua, Guru Tugas yang didatangkan dari tahun ke tahun selalu mengalami perubahan, sehingga berpengaruh terhadap pengetahuan anak, terutama terhadap cara mengajarnya.

\section{APLIKASI METODE AL-GHOYAH DI PONDOK PESANTREN BAHRUL ULUM}

Metode Al-Ghoyah adalah sebuah nama metode membaca tulisan arab, menterjemah (alih bahasa) dan memahami isi kandungan dari sebuah kitab atau tulisan arab seperti al-qur'an, hadist, dan sebagainya. ${ }^{15}$ Implementasi metode alGhoyah pada PP. Bahrul Ulum dimulai sejak tahun 2013, sebagai revolusi metode pembelajaran kitab kuning dan usaha dalam meningkatkan kemampuan membaca kitab santri. ${ }^{16}$ Untuk mengaplikasikan metode ini, terdapat beberapa tahapan yang dilakukan oleh pesantren, yaitu sebagaimana berikut:

\section{Persiapan}

Dalam tahap ini, pengurus menyiapkan hal-hal terkait unsur-unsur utama dalam metode al-Ghoyah. Unsur utama dari Metode Al-Ghoyah meliputi 4 unsur yaitu waktu, tenaga, biaya, dan kedalaman materi, yang dijelaskan sebagai berikut:

15 A. Khoirul Anam, "Metode Al-Ghoyah Permudah Belajar Baca Kitab Kuning (13 Juli 2013), https://www.nu.or.id/post/read/45804/metode-al-ghooyah-permudah-belajar-baca-kitab-kuning. Diakses pada 31 Mei 2019.

16 Berdasarkan hasil wawancara dengan pengurus pesantren 


\section{a. Waktu}

Waktu itu sangat penting dalam sebuah metode, karena metode itu merupakan cara untuk mencapai suatu pembelajaran. Metode al-Ghoyah merupakan metode yang meliputi waktu yang sangat singkat, dalam waktu 40 jam sudah bisa membaca, menterjemah dan memahami isi kandungannya. 40 jam merupakan waktu yang dibutuhkan untuk menerapkan Metode Al-Ghoyah. Jika perharinya I jam maka jumlah pertemuannya 40 x tatap muka. Jika perharinya 2 jam maka jumlah pertemuannya 20x tatap muka. Jika perharinya 4 jam maka jumlah pertemuannya $7 x$ tatap muka.

Dengan memperhatikan pola tersebut, maka pengurus membuat skema alokasi waktu pembelajaran sebagaimana berikut.

\begin{tabular}{|l|l|l|l|}
\hline No & Ketentuan & Waktu Per Hari & Durasi Waktu Yang Dibutuhkan \\
\hline 1 & \multirow{5}{*}{40 jam } & 1 jam & 40 hari \\
\cline { 3 - 4 } 2 & 1,5 jam & 27 hari \\
\hline 3 & 2 jam & 20 hari \\
\hline 4 & & 2,5 jam & 16 hari \\
\hline
\end{tabular}

b. Tenaga

Tenaga yang dimaksud disini adalah sumber daya manusia (SDM) yang ada di pesantren yang meliputi guru dan santri. Untuk menerapkan metode al-Ghoyah, pengurus PP. Bahrul Ulum mempertimbangkan beberapa hal terkait guru dan santri yaitu: Domisili Santri dan guru, Lingkungan Belajar santri, dan Usia santri.

c. Cost atau biaya

Dalam keterangan tentang biaya ini, semua metode atau semua pekerjaan itu ada biaya, termasuk kita mondok membayar uang iuran dan sebagainya, Metode alGhoyah pun demikian, setiap kitab memiliki biaya berbeda. Gambarannya adalah ketika kita belajar membaca kitab al-Jurumiyah di sebuah pesantren, berapa waktu yang kita butuhkan untuk bisa membaca kitab tersebut, semisal menghabiskan biaya 7.200.000, dengan rincian sebagai berikut:

\begin{tabular}{|l|l|l|}
\hline \multicolumn{1}{|c|}{ Waktu } & \multicolumn{1}{c|}{ Pertemuan } & \multicolumn{1}{c|}{ Biaya } \\
\hline 1 hari & 2 jam & 20.000 \\
\hline 1 bulan & 60 jam & 600.000 \\
\hline 1 tahun & 720 jam & 7.200 .000 \\
\hline
\end{tabular}


Selain kitab al-Jurumiyah, juga ada beberapa kitab yang menggunakan metode al-Ghoyah dalam pembelajarannya, berikut rincian dana/tarif untuk setiap kitab.

\begin{tabular}{|l|l|l|l|}
\hline No & Nama Kitab & Pertemuan & Biaya \\
\hline 1 & Amtsilah at-Tasrif & 1 jam & 10 ribu \\
\hline 2 & Qawidul I'lal & 1 jam & 10 ribu \\
\hline 3 & Kailani & 1 jam & 15 ribu \\
\hline 4 & Imriti & 1 jam & 20 ribu \\
\hline 5 & Al-Qur'an & 1 jam & 20 ribu \\
\hline
\end{tabular}

Dengan datangnya metode al-ghoyah ini, memberi sebuah pemahaman bahwa dengan penerapan metode al-ghoyah bisa mencapai pelajaran dengan waktu yang sangat singkat dan cepat.

Rumus dalam cost :

\section{Waktu $x$ tenaga $x$ biaya $=$ hasil}

\section{d. Kedalaman materi}

Dalam sebuah pembelajaran, pendalaman materi adalah target yang harus dicapai, untuk mencapai materi yang sempurna, tentunya harus memahami rumusrumus dalam Metode Al-Ghoyah ini. Rumus-rumus dalam metode al-ghoyah itu sangat banyak, salah satunya yang dipakai sebagai acuan oleh PP. Bahrul Ulum adalah menggunakan struktur berfikir sebagaimana berikut :

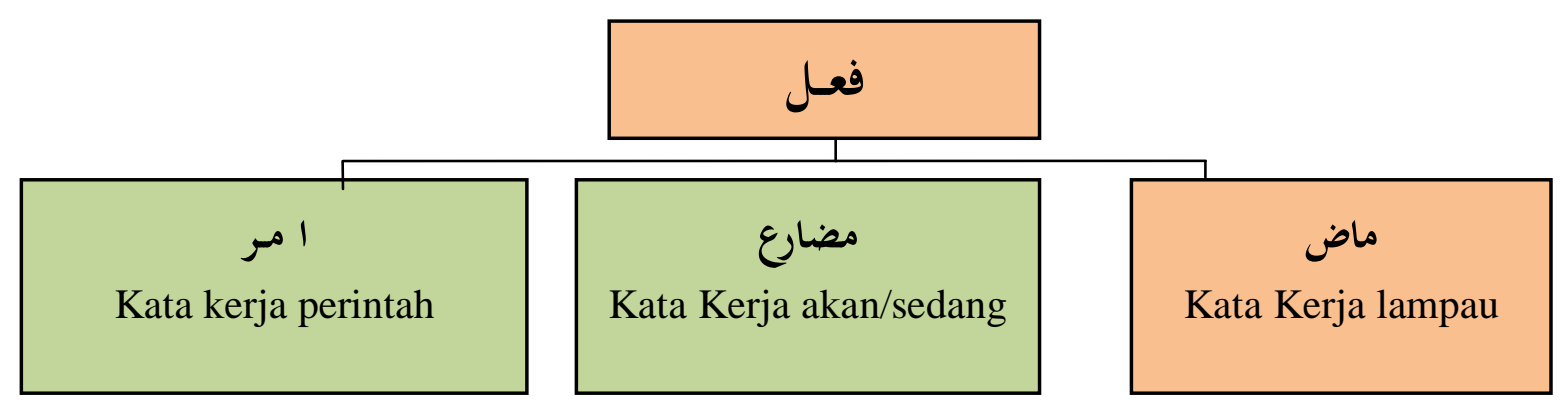

Berikut contoh materi tentang Fi'il Madhi.

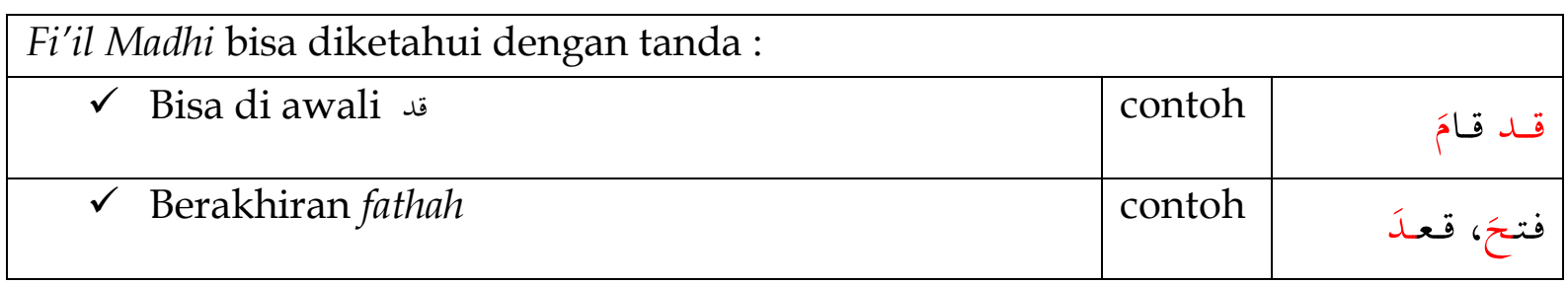




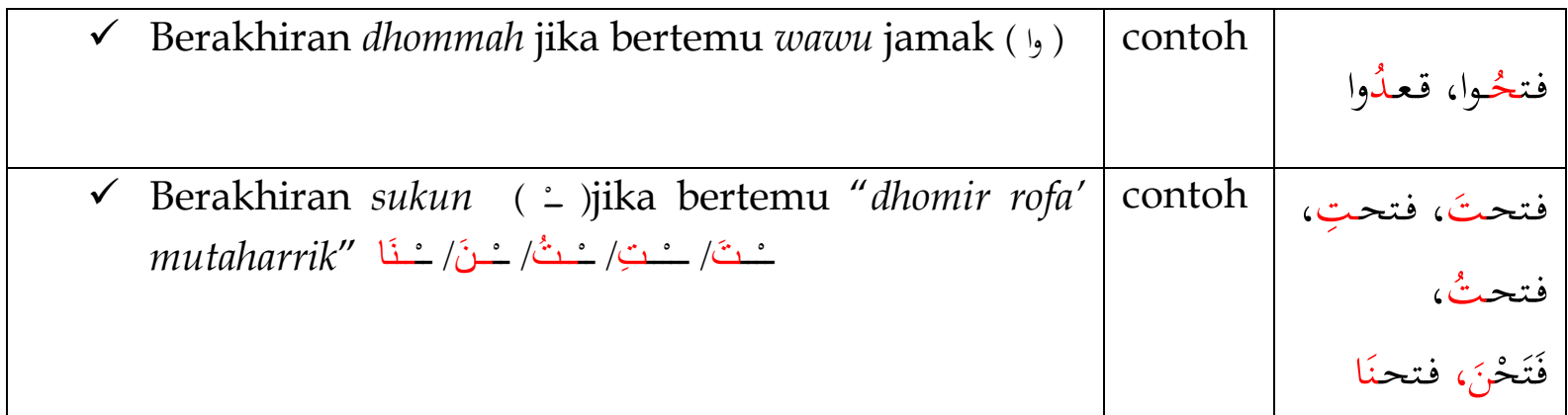

Berikut contoh Tabel Isian:

\begin{tabular}{|c|c|c|c|c|c|}
\hline مै & مَسَْْرَ بَـ & أنتُاسِ & كُلُّ & عَلَّمِ & قَدْ \\
\hline & & & & فعل & حرف \\
\hline & & & & ماض & \\
\hline & & & & 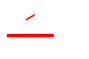 & \\
\hline
\end{tabular}

Setelah merumuskan keempat hal tersebut kemudian ditetapkanlah jadwal pembelajaran dan pembaiyaan sebagaimana berikut.

\begin{tabular}{|l|l|l|l|l|l|}
\hline No & Nama Kitab & Jenjang Usia & $\begin{array}{l}\text { Waktu } \\
\text { Per Hari }\end{array}$ & $\begin{array}{l}\text { Durasi } \\
\text { Waktu Yang } \\
\text { Dibutuhkan }\end{array}$ & Biaya \\
\hline 1 & Al-Qur'an & Remaja/Dewasa & 2 jam & 20 hari & 800 ribu \\
\hline 2 & Al-Jurmiyah & $\begin{array}{l}\text { Remaja/kanak- } \\
\text { kanak }\end{array}$ & 2 jam & 20 hari & 400 ribu \\
\hline 3 & Amtsilah at-Tasrif & $\begin{array}{l}\text { Remaja/kanak- } \\
\text { kanak }\end{array}$ & 2 jam & 20 hari & 400 ribu \\
\hline 4 & Qawidul I'lal & $\begin{array}{l}\text { Remaja/kanak- } \\
\text { kanak }\end{array}$ & 2 jam & 20 hari & 400 ribu \\
\hline 5 & Kailani & Remaja/Dewasa & 2 jam & 20 hari & 600 ribu \\
\hline 6 & Imriti & Remaja/Dewasa & 2 jam & 20 hari & 800 ribu \\
\hline
\end{tabular}

\section{Pelaksanaan}

Jadwal yang ada di atas ditawarkan kepada stakeholder dan dilaksanakan sebagaimana adanya. Pada PP. Bahrul Ulum, bahan yang sudah ditetapkan, metode Al-Ghoyah digunakan dalam pembelajaran dengan serta penerapannya sebagai berikut:

a. al-Qur'an

Penerapannya untuk pemula pada surat الفاتحة - البقرةdengan meng i'rob sampai 40 ayat pada surat البقرة dan itu dinilai bagus. Kalau pencapaian mengi'rob itu sampai 
287 ayat maka penilaiannya adalah istimewa. Dan begitu seterusnya hingga surat terakhir dalam al-Qur'an.

b. Amshilatut Tasrif

Dalam penerapannya, para santri diminta untuk menghafal 1 tartib wazan dengan membaca bersama berulang kali kurang lebih selama 30 menit. Kemudian, santri diminta untuk pencapaian pada ilmu sorrof ini hanya bisa ditempuh dalam waktu 4 jam dan paling cepat itu bisa 1 jam. Dengan waktu yang sangat singkat tersebut bisa memahami ilmu sorrof.

c. Al-Jurumiyah

Penerapan Kitab al-Jurumiyah dengan melakukan kajian i'rab setiap pertemuan sebanyak 1 bab, yang dilakukan dengan menunjuk 1 santri untuk mengi'rab 1 jumlah (kalimat) secara bergantian, dengan mengikuti arahan guru. Setelah itu, santri diminta dan melafadzkan arti dari setiap kata secara berurut. Dan diakhir pertemuan disimpulkan dan dijelaskan secara komperhensif oleh guru. Penerapan metode al-Ghoyah pada ketiga kitab yang lain, yakni Qawaidul I'lal, Kailani dan Imriti tidak jauh berbeda dengan kitab al-Jurumiyah.

\section{Evaluasi}

Evaluasi terhadap aplikasi Metode al-Ghoyah pada PP Bahrul Ulum dilaksanakan setiap 20 hari sekali. Evalusi dilakukan dengan cara, tes lisan pada setiap santri di masing-masing kluster kitab. Santri diminta untuk membaca bagian kitab yang dipelajari secara acak. Santri dianggap berhasil ketika 90\% bacaan kitab mereka benar.

\section{Kelebihan dan Kekurangan Aplikasi Metode al-Ghoyah di Pondok Pesantren Bahrul ulum}

Setelah dilakukan penelitian selama sekitar 3 bulan, dengan ngingikuti siklus yang sudah ditetapkan oleh PP Bahrul Ulum, ditemukan kelebihan dan kekurangan dalam metode al-Ghoyah.

a. Kelebihan Aplikasi Metode al-Ghoyah di Pondok Pesantren Bahrul Ulum:

1) Metode cepat dalam memahami atau membaca Kitab Kuning dalam waktu 20 hari. 
2) Penerapan metode yang tidak sulit diterima oleh santri pondok pesantren Bahrul Ulum

3) Penampilan pembacaan Kitab Kuning ketika Haflatul Ikhtibar

4) Mengikuti lomba dalam bidang Al-Jurumiyah

b. Kekurangan Aplikasi Metode Al-Ghoyah di Pondok Pesantren Bahrul Ulum yaitu:

1) Kurangnya pembimbing Metode Al-Ghoyah, sebab untuk menerapkan metode ini diperlukan pemahaman yang komperhensif terkait ilmu alat (ilmu tata cara membaca dalam bahasa Arab) dari guru pembimbingnya.

2) Sebelum melaksanakan metode al-Ghoyah, santri harus mengetahui dasardasar ilmu alat.

3) Biaya operasioanal yang terlalu mahal untuk kalangan penduduk sekitar pesantren dan santri, sehingga membebani terhadap santri.

\section{KESIMPULAN}

Aplikasi metode al-Ghoyah pada PP Bahrul Ulum dilakukan dengan menerapkan 3 siklus pembelajaran, yaitu Persiapan, pelaksanaan, dan evaluasi. Dalam aplikasinya, PP Bahrul Ulum melakukan persiapan terstandar pada 4 unsur utama metode ini yaitu, waktu, tenaga, biaya dan pendalaman materi. Begitu pula dalam pelaksanaannya, dalam pelaksanaan mengikuti pola standar metode alGhoyah, yang membutuhkan pendalam materi yang sangat baik dari guru dan santri.

Selain itu, dari hasil evaluasi berkelanjutan, ditemukan kelebihan dan kekurangan dalam pengaplikasian metode ini. Adapun kelebihannya adalah cepat dalam membaca dan memahami Kitab Kuning dalam waktu 20 hari, penerapan metode yang mudah diterima oleh santri, penampilan pembacaan Kitab Kuning ketika Haflatul Ikhtibar, mengikuti lomba dalam bidang Al-Jurumiyah. Kekurangannya adalah kurangnya pembimbing Metode Al-Ghoyah, santri harus punya pemahaman terhadap ilmu alat, serta mahalnya biaya yang harus dikeluarkan. 


\section{DAFTAR PUSTAKA}

Anam, A. Khoirul. “Metode Al-Ghoyah Permudah Belajar Baca Kitab Kuning (13 Juli 2013), https://www.nu.or.id/post/read/45804/metode-al-ghooyahpermudah-belajar-baca-kitab-kuning. Diakses pada 31 Mei 2019.

Arifi, Ahmad. Politik Pendidikan Islam. Yogyakarta: Sukses Offset. 2010.

Departemen Agama RI. Pola Pembelajaran di Pesantren. Jakarta: Depag RI, 2003.

Ghazali, Bahri. Pesantren Berwawasan Lingkungan. Jakarta: Prasasti, 2002.

Hamdani, Ahmad. "Metode Praktis Buku Amtsilati dalam Peningkatan Baca Kitab Kuning di Pondok Pesantren", dalam Jurnal Pendidikan Islam An Nida Pasca PAI Uninus, Vol 6, No 1, 2017, hal 24-34.

Hanani, Nurul, “Managemen Pengembangan Pembelajaran Kitab Kuning”, dalam Jurnal Realita, Vol. 15, No. 2, Tahun 2017, hlm. 1-25.

Mutohar, Ahmad. Nurul Anam. Manifesto Modernisasi Pendidikan Islam dan Pesantren. Jember: Pustaka Pelajar \& STAIN Jember, 2013.

Solichin, Muhammad Muchlis. Masa Depan Pesantren. Surabaya: Salsabila Putra Pratama, 2013.

Sufa, Azuma Fela. “Efektifitas Metode Pembelajaran Kitab Kuning di Madrasah Diniyah Pondok Pesantren Al-Mahalli Brajan Wonokromo Pleret Bantul Tahun Ajaran 2013/2014", dalam jurnal Literasi, Vol. V No. 2, 2014, hlm. 169-186.

Suharto, Babun. Dari Pesantren Untuk Umat. Surabaya: Imtiyaz, 2011.

Syamsudini, M. Kontribusi Model Pendidikan Pondok Pesantren Darunnajah Kabubaten Banyuwangi. Jember: STAIN Jember, 2008.

Umam, Khotibul. Pernak-Pernik Pesantren. Jember: Pustaka Radja, 2012. 